\title{
PENGEMBANGAN USAHA BATIK MELALUI MESIN PEWARNAAN BATIK DI DESA PILANG KECAMATAN MASARAN KABUPATEN SRAGEN
}

\author{
LV. Ratna Devi S 1,2), Susantiningrum 1,3)
}

1) Pusat Pengembangan Kewirausahaan LPPM Universitas Sebelas Maret

2) Fakultas Ilmu Sosial dan Ilmu Politik Universitas Sebelas Maret

3) Fakultas Keguruan dan Ilmu Pendidikan

Universitas Sebelas Maret

Email: ratnadevi.solo@gmail.com

\begin{abstract}
Pilang Village is one of the villages in Subdistrict of Sragen. This village has a potential in producing batik. Batik is a craft that has high artistic value and has been a part of Indonesian culture (especially in Java) since long. Up till now in Sragen, batik staining has been doing manually; this becomes an obstacle because manual staining takes a long time and sometimes not tidy. To overcome this, then the officials provide a dye machine batik, i.e., Fider machine. The benefits gained from the implementation of this activity are to help improve the quality of production, help develop the business of batik SME Karya Mandiri, and help improve the professionalism and productivity of batik craftsmen group, in order to achieve the formation of groups of batik craftsmen. Methods used to help overcome the problems that have been agreed above are through business management training, training and partial support of production equipment support and mentoring.

Key words: Batik, Fider Machine, SME
\end{abstract}

\begin{abstract}
ABSTRAK
Desa Pilang merupakan salah satu desa di Kecamatan Sragen. Desa ini memiliki potensi dalam memproduksi batik. Batik adalah kerajinan yang memiliki nilai seni tinggi dan telah menjadi bagian dari budaya Indonesia (khususnya Jawa) sejak lama. Selama ini pewarnaan batik di daerah Sragen masih berupa manual, hal ini menjadi kendala karena pewarnaan manual membutuhkan waktu lama dan kadang tidak rapi. Untuk mengatasi hal tersebut maka, pengabdi memberikan mesin pewarna batik yaitu mesin Fider. Manfaat yang diperoleh dari pelaksanaan kegiatan ini adalah membantu meningkatkan kualitas produksi, membantu mengembangkan usaha batik UKM Karya Mandiri, dan membantu meningkatkan profesionalitas serta produktivitas kelompok perajin batik guna tercapainya tujuan terbentuknya kelompok pengrajin batik tersebut. Metode yang digunakan untuk membantu
\end{abstract}


mengatasi persoalan-persolan yang telah disepakati di atas adalah melalui pelatihan manajemen usaha, pelatihan dan pemberian sebagian bantuan dukungan alat produksi, dan pendampingan.

Kata Kunci : batik, mesin fider, UKM

\section{PENDAHULUAN}

Kabupaten Sragen hingga kini memiliki sebanyak 4.542 unit usaha batik tulis dengan jumlah perajin batik lebih dari 12.353 orang yang sebagian besar tersebar di Desa Pilang, Kliwonan dan Sidodadi yang terletak di Kecamatan Masaran. Khusus untuk Kecamatan Masaran terdapat 2.567 unit usaha batik yang mampu menyerap tenaga kerja 7.233 orang. Perajin batik Sragen setiap bulan mampu memproduksi sebanyak 1.201.500 potong bahan batik untuk konsumsi pasar domestik seperti Pulau Jawa dan luar Pulau Jawa.

Industri batik merupakan salah satu dari 14 kelompok klasifikasi industri kreatif di Indonesia sebagai ciri khas bangsa Indonesia yang dikenal di mancanegara (Disperindag, 2007). Kerajinan batik terkenal di dunia karena memiliki pola rumit yang indah, desain halus, serta warna yang khas. Industri batik nasional semakin berkembang akibat semakin banyaknya permintaan terhadap batik, sejak dicanangkan hari batik nasional pada tanggal 2 Oktober 2009 omset pengusaha batik naik hingga 50\% (Suhendra, 2009). Akan tetapi munculnya batik printing atau tekstil dengan motif batik, berakibat banyaknya pengrajin batik tulis dan cap mengurangi kegiatannya dan bahkan mengancam para pengrajin untuk menutup perusahaannya. Berkembang batik sablon atau printing yang terus menggerogoti pasar batik tradisional mengharuskan para pengrajin untuk berinovasi dan berfikir kreatif guna menjaga kualitas produk untuk tetap bersaing dengan batik printing.

Pewarnaan adalah salah satu proses produksi batik yang juga berpengaruh pada nilai jual batik. Dalam pembuatan batik tulis serta cap pada proses pewarnaan memiliki tingkat kesulitan tersendiri untuk mendapatkan warna yang merata. Proses pewarnaan batik umumnya dilakukan secara manual. Adapun kendala pewarnaan batik secara manual untuk keperluan pewarnaan kain dengan panjang kain yang melebihi panjang 2.5 meter dirasa kurang efektif, memakan terlalu banyak zat warna, serta warna yang kurang merata. Untuk mengurangi resiko ketidakrataan dalam pewarnaan serta agar efisien baik secara ekonomi maupun tenologi pewarnaan dengan mesin pewarnaan batik maka dibutuhkan teknologi mesin pewarna, yang dinamakan feeder. Feeder merupaka mesin alat pewarnaan batik dengan sistem motor yang dapat memudahkan para pengrajin guna mendapatkan kualitas produksi batik tradisional. 


UKM Karya mandiri
merupakan salah satu dari sekian
banyak pengrajin batik tradisional
di Kabupaten Sragen yang tengah
mengembangkan usahanya dengan
mempekerjakan ibu-ibu rumah
tangga serta para pemuda setempat
guna mensejahterakan
kehidupanya. Bapak Daryadi
(Pemilik UKM Karya Mandiri)
menyampaikan tidak dipungkiri
bahwa terdapat kendala dalam
menjalankan bisnis produksi batik
tradisional terlebih UKM Karya
mandiri merupakan unit usaha
yang tengah merintis pembesaran
usahanya.

Adapun kendala yang dihadapi olah UKM tersebut diantaranya pada persediaan bahan baku produksi. Dalam memperoleh bahan baku produksi ditempuh jarak yang cukup jauh dari tempat produksi, yang mengharuskan UKM mengeluarkan ongkos transport yang tidak sedikit. Selain permasalahan terebut, proses pewarnaan juga menjadikan permasalahan, diantaranya sulit mendapatkan warna yang merata, kurang efisien dalam penggunaan zat pewarna dan tenaga pada proses pewarnaan, serta terbatas dalam pemasaran. Selain UKM Karya Mandiri, Terdapat kelompok Pengrajin Batik Desa Pilang yang dibentuk dengan tujuan mewadahi pengrajin batik dalam mendapatkan akses mengenai bahan baku produksi, teknologi baru, dan pemasaran. Keberadaan kelompok dapat menimbulkan rasa solidaritas anggota sehingga dapat saling menghormati dan saling menghargai pendapat.

Pada dasarnya kelompok merupakan penggabungan informasi, ide, pengalaman, dan pendapat dari anggota adalah bagian mendasar dalam pemecahan masalah kelompok. Adapun permasalahan yang muncul pada kelompok batik tersebut yaitu permasalahan dalam kegiatan operasionalnya terutama dalam menejemen usaha yaitu kurangnya semangat kewirausahaan serta minimnya pengelolaan keuangan yang berdampak belum tercapainya visi dan misi kelompok pengrajin batik desa pilang.

Oleh karena itu, diperlukan pendampingan pada kelompok pengrajin tersebut yaitu dengan dikenalkanya teknologi mesin pewarnaan batik untuk dapat di aplikasikan pada pengrajinpengrajin di desa Masaran guna mengefisiensikan proses produksi batik hingga berdampak pada meningkatnya omset usahanya. Selain itu pelatihan peningkatan kemampuan dalam hal manajemen usaha (manajemen keuangan, pembukuan dan manajemen pemasaran) juga perlu di lakukan guna memotivasi dan meningkatkan kesejahteraan anggota serta dapat menciptakan wadah pengrajin batik dalam mendapatkan akses mengenai bahan baku produksi, teknologi baru, dan pemasaran produk batik di Desa Masaran Kecamatan Sragen. 


\section{METODE}

Metode yang digunakan untuk membantu mengatasi persoalan-persolan yang telah disepakati di atas adalah melalui pelatihan manajemen usaha, pelatihan dan pemberian sebagian bantuan dukungan alat produksi, dan pendampingan:

A. Metode Kegiatan

1. Pelatihan in class dan out class

Pelatihan kewirausahaan bagi pengrajin batik guna meningkatkan motivasi pengrajin batik dalam meningkatkan hasil produksi kain batik.

2. Peningkatan Kemampuan Teknologi Produksi.

Peningkatan kemampuan UKM Karya Mandiri dalam hal pewarnaan batik.

3. Peningkatan kemampuan dalam hal pengelolaan usaha, dalam hal ini efektivitas manajemen usaha (manajemen keuangan, pembukuan dan manajemen pemasaran).

4. Evaluasi kegiatan dilakukan pada dua aspek yaitu, evaluasi proses dan evaluasi produk. Evaluasi proses dimaksudkan untuk mengetahui keefektifan proses berlangsungnya kegiatan program.

B. Partisipasi Mitra dalam Pelaksanaan Program :

Dalam melaksanakan kegiatan ini, UKM Mitra Mandiri dan Kelompok pengrajin batik Desa Pilang, Kecamatan Masaran, Kab. Sragen bersedia mengikuti seluruh kegiatan yang telah ditetapkan sesuai dengan kesepakatan bersama. Hal ini dibuktikan dengan surat kesediaan berkerjasama antara PPKwu UNS dengan mitra program IbM. Selama kegiatan, kedua mitra berpartisipasi aktif melalui berbagai kegiatan yang akan ditransfer kepada mitra IbM.

\section{HASIL DAN PEMBAHASAN}

Kegiatan pengabdian masyarakat ini bertujuan untuk membantu meningkatkan kualitas produksi, membantu mengembangkan usaha batik UKM Karya Mandiri, pada manajemen usaha terutama pada proses pewarnaan produksi batik, dan sistem pemasaran, dan membantu meningkatkan profesionalitas serta produktivitas Kelompok pengrajin batik guna tercapainya tujuan terbentuknya kelompok pengrajin batik tersebut. Pada tanggal 20 Mei 2016, tim pengabdi mengadakan koordinasi dengan mitra untuk mengetahui permasalahan yang dihadapi dan mencari permasalahannya. Dalam rapat tersebut ditemukan fakta bahwa, mitra membutuhkan mesin pewarna batik berupa mesin Fider agar produktivitas usaha batik semakin meningkat.

Mesin pewarna batik dengan teknologi sangat berguna bagi mitra. Tanggal 4 Agustus 2016, tim pengabdi mengunjungi desa Pilang Kecamatan Masaran Kabupaten Sragen. Selain mengunjungi mitra, diadakan pula pelatihan outclass yakni pelatihan 
penggunaan mesin Fider. Menurut mitra, pewarnaan batik menggunakan mesin Fider lebih jelas hasilnya. Hal ini akan meningkatkan nilai jual dari batik sehingga produktivitas semakin tinggi.

Pelatihan penggunaan mesin pewarna batik yang sudah dilakukan, memberikan dampak positif bagi UKM Karya Mandiri. Pelatihan ini memberikan beberapa manfaat diantaranya meningkatkan harga jual kain batik yang telah dibuat. Pada tanggal 14 September 2016 dilakukan pelatihan in class. Pelatihan ini dilakukan untuk memberikan masukan kepada UKM Karya Mandiri agar bisa memanage keuangan, pemasaran, dan lain-lain yang mendukung keberlangsungan usaha UKM Karya Mandiri. Sejauh ini belum ada manajemen yang baik di UKM Karya Mandiri. Dengan adanya pelatihan ini diharapkan kedepannya UKM Karya Mandiri bisa lebih mengontrol keuangannya sehingga antara pemasukan dan pengeluaran lebih tertata. Selain itu, tim pengabdi juga memberikan cara bagaimana memanage pemasaran agar para pembeli tertarik dengan produk UKM Karya Mandiri.

\section{KESIMPULAN}

Pewarnaan batik merupakan salah satu proses produksi batik yang juga berpengaruh pada nilai jual batik. Proses pewarnaan batik umumnya dilakukan secara manual. Setelah diberikan mesin
Fider dari tim pengabdi ke UKM Karya mandiri, Bapak Daryadi (Pemilik UKM Karya Mandiri) menyampaikan kebermanfaatan dari mesin tersebut. Salah satu kebermanfaatannya adalah warna batik terlihat lebih jelas dan harga jual batik semakin meningkat. Hal ini sejalan dengan tujuan awal dari pengabdian yaitu memberikan berbagai manfaat diantaranya membantu meningkatkan kualitas produksi dan membantu mengembangkan usaha batik UKM Karya Mandiri. Selain itu hal ini juga membantu meningkatkan profesionalitas dan produktivitas kelompok pengrajin batik UKM Karya Mandiri Desa Pilang Masaran Sragen. Selanjutnya, tim pengabdi berharap UKM Karya Mandiri lebih disiplin dalam mengelola manajemen keuangan sehingga dapat membeli mesin baru

\section{DAFTAR PUSTAKA}

Pandji Anoraga. 2002. Koperasi, Kewirausahaan, dan Usaha Kecil. Rineka Cipta. Jakarta.

Ratna, S., dkk. 2003. Dinamika Kelompok. Lembaga Administrasi Negara. Jakarta.

Santosa, S. 2004. Dinamika Kelompok. PT Bumi Aksara. Jakarta.

Tjiptoherijanto, Prijono dan Sutyastie Soemitro, 1998. Pemberdayaan Penduduk dan Peningkatan Sumber Daya Manusia. PT Cita Putra Bangsa, Jakarta. 